\title{
Aydın İlinde Termofilik Çevreden İzole Edilen Mayaların Moleküler Tanısı
}

\author{
H. Halil BIYIK ${ }^{1 *}$, Esin POYRAZOĞLU ÇOBAN ${ }^{1}$, \\ Yusuf GEROĞLU', IlgIt KIRGIZ1
}

${ }^{1}$ Adnan Menderes Üniversitesi, Fen Edebiyat Fakültesi, Biyoloji Bölümü, AYDIN

Öz: Termofilik mayaların izolasyonu için Aydın ili Buharkent ilçesi Bereket Jeotermal tesislerinin çevresindeki toprak ve su örnekleri materyal olarak kullanılmıştır. Elde edilen veriler ve analizler sonucunda, izolatların $\% 98$ ve $\% 99$ gibi değişen oranlarda belirli türlerinin ITS1 ve ITS2 bölgeleriyle homoloji gösterdiği tespit edilmiştir. Bu türlerin GenBank'ta kayıtlı Saccharomyces cerevisiae strain levure 23, Candida albicans, Candida albicans strain m74a, Cyberlindnera jadinii strain ATCC 22023, Saccharomyces cerevisiae, Kluyveromyces marxianus strain P2, Pichia manshurica strain h79b, Candida glabrata strain 86A adlı maya suşları olduğu belirlenmiştir.

Anahtar kelimeler: Toprak, Su, Termofilik maya, İzolasyon, ITS, Filogenetik analiz.

\section{Molecular Identification of Yeasts Isolated from Thermophilic Environment in Aydın Province}

\begin{abstract}
For the isolation of thermophilic yeasts, soil and water samples around of Bereket geothermal plants in Buharkent district of Aydin province were used as material. As a result of the obtained data and analyzes, it was determined that certain strains showed homologies with the regions of ITS1 and ITS2 at the rates of $98 \%$ and $99 \%$ of the isolates. These species are registered in GenBank Saccharomyces cerevisiae strain levule 23, Candida albicans, Candida albicans strain m74a, Pichia jadinii strain ATCC 22023, Saccharomyces cerevisiae, Kluyveromyces marxianus strain P2, Cyberlindnera jadinii strain $\mathrm{h} 79 \mathrm{~b}$ and Candida glabrata strain $86 \mathrm{~A}$ are identified as yeast species.
\end{abstract}

Key words: Soil, Water, Thermophilic yeast, Isolation, ITS, Phylogenetic analysis.

\section{Giriş}

Mayalar doğada yaygın olarak bulunan genellikle tek hücreli, ökaryotik mantarlardır. Maya türleri zorunlu aerobik veya fakültatif anaerobik özelliğe sahiptirler. Mayalar tomurcuklanma yoluyla eşeysiz ve eşeyli olarak ürerler. Çoğu maya, yüksek şekerli çevresel örneklerden izole edilebilir. Üzüm, elma veya şeftali gibi meyvelerde bitki özsuyu sızmalarında bulunur. Bazı mayalar da toprak ve böceklerde bulunur (Lee,1996).

Birçok maya, Ascomycota bölümüne ait olmakla beraber bazıları Basidiomycota'ya aittirler. Candida albicans gibi bazı maya türleri insanlarda enfeksiyona yol açabildiği gibi Rhodotorula türleri de duş perdelerinde ve evdeki nemli yüzeylerde yaşar ve yüzeyler üzerinde lekeli bir görünüm oluşturur (Pfaller ve Diekema, 2004; Charles ve ark., 2005).

Bazı mayaların insanlarda ve çevrede yarattıkları olumsuz etkileri olmasına rağmen birçok maya türünün faydalı fizyolojik özellikleri olması nedeniyle biyoteknoloji alanında kullanılmaları çok yaygındır. 
Mayalar endüstriyel proseslerde en fazla kullanılan mikroorganizmalardandır. Çeşitli gıdaların hem üretilmelerinde hem de bozulmalarında önemli role sahiptirler. Fermantasyon yeteneklerinin çok yüksek olması nedeniyle alkol, şarap, bira ve ekmek endüstrisinde çok geniş bir kullanım alanı bulmuşlardır (Vaughan-Martini, 2003). Mayaların ökaryotik hücre yapısında olmaları, laboratuvar şartlarında kolayca üretilebilmeleri ve genetik düzeyde manipulasyonlar yapılabilmesi gibi özellikleriyle moleküler biyoloji çalışmalarında da önemli bir yeri vardır (Lopes ve ark., 1998).

Son yıllarda yapılan çalışmalar mikrobiyal yaşamın spesifik çevrelerle sınırlı olmadığını, mikrobiyal komünitelerin yüksek sıcaklık, yüksek tuz, düşük sıcaklık, asidik, alkali pH ve yüksek basınç gibi ekstrem olarak bilinen çevrelerde de bulunabileceğini ortaya koymuştur. Bu ekstrem çevrelerde yaşayan mikroorganizmalar ekstremofiller olarak adlandırılırlar (Van den Burg, 2003). Ekstremofilik mikroorganizmaların, yüksek sıcaklıkta yaşayan üyeleri termofillerdir. Yüksek sıcaklıkta üreme, diğer mikroorganizmalar ile kontaminasyon riskini de azaltır. Ayrıca termofilik mayaların enzimleri özel avantajlara sahiptir.

Enzim teknolojisinin giderek gelişmesi ürünlerin kullanım alanlarının çeşitliliği ve ekonomik değerinin çok yüksek olması nedeniyle biyoteknolojinin endüstriyel enzimler ile ilgili alanında yapılan çeşitli araştırmalar daha da önem kazanmaktadır. Özellikle son yıllarda stratejik alan şeklinde değerlendirilen rekombinant DNA teknolojisinden yararlanılarak enzim üretimi büyük boyutlara ulaşmış ve kullanımı giderek yaygınlaşmıştır (FernandezEspinar ve ark., 2006). Etanol üretimi için de termofilik mikroorganizmalardan yararlanma mümkündür ve birçok avantaj sağlamaktadır.

Taksonomide kullanılan geleneksel yöntemler, mikroorganizmaların ekolojik kaynak, morfoloji, fizyoloji ve üreme gibi fenotipik özelliklerini belirlemeye dayanmaktadır. Biyoteknolojik olarak büyük bir öneme sahip olan maya türlerinin klasik yöntemle tanılanması hem zaman alıcı hem de daha az güvenilirdir. Bu nedenle son yıllarda mayaların tanımlanması ile ilgili DNA esaslı değişik yöntemler üzerinde durulmuştur (Lopes ve ark., 1998; VaughanMartini, 2003). Moleküler taksonomi alanında yapılan ilk çalışmaların ardından tanımlamada; ribozomal RNA (rRNA) veya tamamlayıcı molekülü olan ribozomal DNA (rDNA)'daki belirli bölgelerin hedeflendiği çeşitli tekniklerin geliştirildikleri ve günümüzde de sıklıkla kullanıldıkları bilinmektedir (Vaughan-Martini, 2003; Hierro ve ark., 2004). Filogenetik çalışmalarda da kullanılan bu yöntemler; $26 S$ rDNA, 18S rDNA veya 18rDNA' daki ara bölgelerin (ITS1, ITS2, ITS3, ITS4) tanımlanmasına yöneliktir. Günümüzde, DNA baz dizi analizi çalışmaları sonucunda oldukça fazla sayıda veri bankasının oluşturulması ve PCR teknolojisinin geliştirilmesiyle, mayaların hızlı ve doğru bir şekilde tür ve suş düzeyinde tanımlanmaları mümkün olabilmektedir (Lopes ve ark., 1998; Van Der Vossen ve ark., 2003).

$\mathrm{Bu}$ çalışma ile Aydın ilinde termofilik çevrelerden izole edilen termofilik maya suşlarının PCR tekniği kullanılarak hızlı ve doğru bir şekilde tanılanmaları ve tanılanan suşların bir sonraki çalışmalarda endüstriyel kullanım potansiyellerinin araştırılması amaçlanmıştır.

\section{Materyal ve Metot Toprak Örneklerinin Toplanması}

Aydın ilinde Buharkent Bereket Jeotermal Su kaynağı çevresinden (Enlem: $37^{\circ} 56^{\prime \prime} 62^{\prime}$; Boylam: 28 51"51' ; Yükseklik: 138 m) 7 adet toprak, 2 adet su örneği aseptik koşullara uygun olarak alınmıştır. Örnekler steril kilitli poşetlere konularak laboratuvara getirilmiştir (Zhang ve ark., 2014).

\section{Mayaların İzolasyonu}

Laboratuvara getirilen toprak ve su örnekleri, $10^{-1}, 10^{-2}, 10^{-3}$ ve $10^{-4}$ e kadar seyreltilerek dilüsyonları hazırlanmıştır.

Hazırlanan seyreltmelerden sodyum propiyonat içeren YGC agar (\%4 Yeast Extract Glucose Chloramphenicol Agar, \% 0,1 Sodyum Propiyonat) petrilerine yayma ekim tekniği kullanılarak, ekim yapılmıştır. 
25-30 ${ }^{\circ} \mathrm{C}$ de 3-7 gün inkübe edildikten sonra maya kolonileri seçilerek, YEP Agar (10 g/L Yeast Extract, $20 \mathrm{~g} / \mathrm{L}$ Bacto-peptone, $20 \mathrm{~g} / \mathrm{L}$ Agar, $20 \mathrm{~g} / \mathrm{L}$ Dextrose) besiortamında geliştirilmiş ve $200 \mathrm{~g} / \mathrm{L}$ skim milk içerisinde saklanmıştır (Genç ve Çıldır, 2012; Zhang ve ark., 2014).

\section{Moleküler Tanılama}

DNA izolasyonu, Hoffman ve Winston (1987)'nin modifiye edilmiş metodu ile gerçekleştirilmiştir. Maya izolatları YEP Agar'da $30{ }^{\circ} \mathrm{C}$ de 24 saat geliştirildikten sonra hücreler 1 $\mathrm{mL}$ steril distile suda süspanse edilmiştir.14,000 rpm de 2 dk santrifüj edilerek, hücreler toplanmış ve fenol-kloroform yöntemi uygulanmıştır. Elde edilen DNA ekstraksiyonu \%1'lik agaroz jel elektroforezinde yürütülmüştür.

$\% 1$ konsantrasyonda 0,5 X TBE tamponu ile hazırlanan $100 \mathrm{~mL}$ 'lik agaroz jel içine ticari olarak satılan SafeView jel görüntüleme boyasından $3.5 \mu \mathrm{L}$ konulmuştur. Donan jel kuyucuklarına DNA örneğinden $5 \mu \mathrm{L}$, 6X Loading Dye DNA çöktürme boyasından $5 \mu \mathrm{L}$ ile karıştırılarak kuyucuklara doldurulmuştur. İlk kuyucuğa DNA'nın büyüklüğünü anlamak için marker olarak $1 \mathrm{~kb}$ 'ık DNA Ladder eklenmiştir. DNA'nın jeldeki görüntüsünü elde etmek için 40 dakika elektrik akımı (80 volt) uygulanmıştır. DNA UV görüntüleme cihazında görüntülenmiştir. Total DNA konsantrasyonu ve DNA kirliliği de NanoDrop'ta ölçüm yapılarak belirlenmiştir.
PCR denemesi, Dlauchy ve ark., (1999)'na göre yapılmıştır. $30 \mu \mathrm{L}$ reaksiyon hacmi için 0,5 $\mu \mathrm{L}$ DNA polimeraz $(2 \mathrm{U} / \mu \mathrm{L}, 0,3 \mu \mathrm{L}$ dNTP, $3 \mu \mathrm{L}$ 10X tampon, $3 \mu \mathrm{L} \mathrm{MgCl}_{2}(25 \mathrm{mM}), 3$ $\mu \mathrm{L}$ primer $(10 \mathrm{Mm})$ kullanılmıştır. PCR denemesi, White ve ark. (1990)'nın tanımladığı primerler ile gerçekleştirilmiştir.

\section{ITS1 $\left(5^{0}\right.$-TCCGTAGGTGAACCTGCGG- $\left.3^{0}\right)$ ITS4 $\left(5^{\circ}\right.$-TCCTCCGCTTATTGATATGC- $\left.3^{\circ}\right)$}

PCR koşulları, $94^{\circ} \mathrm{C}$ de $5 \mathrm{dk}, 57^{\circ} \mathrm{C}$ de 30 sn, $72{ }^{\circ} \mathrm{C}$ de $1 \mathrm{dk}, 72{ }^{\circ} \mathrm{C}$ de $5 \mathrm{dk}$ olarak yapılmıştır.

Elde edilen PCR ürünlerinin sekansı Almanya'daki GATC BIOTECH Firması tarafından gerçekleştirilmiş ve sekans analizi $A B I$ Primse sekans sistemi ile yapılmıştır.

\section{Filogenetik Ağacın Oluşturulması}

Filogenetik ağaç, $300 \mathrm{bç-700bç}$ arasındaki uzunluğunda diziler baz alınarak neighborjoining metot kullanılarak oluşturulmuştur (bootstrap analizleri 1000 tekrarlı olarak gerçekleştirilmiştir).

\section{Bulgular \\ Mayaların İzolasyonu}

Aydın ilinde Buharkent Bereket Jeotermal Su kaynağı çevresinden maya izolasyonu için toprak ve su örnekleri alınmıştır (Şekil 1). Fakat sadece toprak örneğinden maya izolasyonu yapılabilmiştir (Tablo 1).

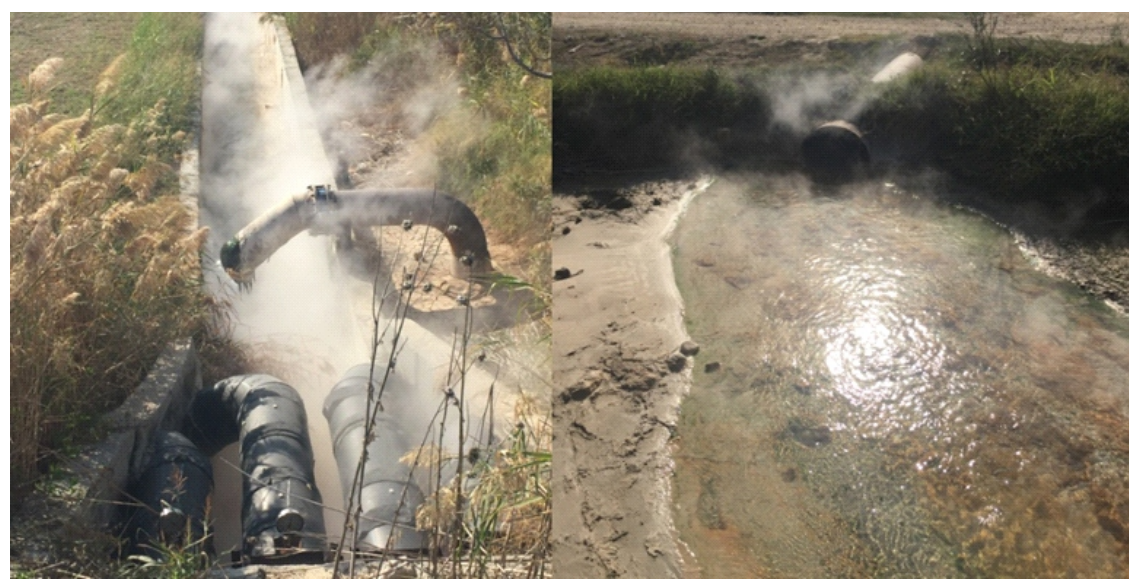

Şekil 1.Aydın ili Buharkent Bereket Jeotermal Su kaynağı. HBM1, HBM2; HBM3, HBM4, HBM5, HBM6, HBM7, HBM8, HBM9 izolatları için alınan su ve toprak örneklerinin doğal görüntüsü. 
Tablo 1.Maya izolasyonu için alınan örnek çeşitleri ve izolat numarası

\begin{tabular}{l|l}
\hline Örnek Çeşitleri & İolat Numaras I \\
\hline Toprak (1) & HBM1, HBM2 \\
\hline Toprak (2) & HBM3 \\
\hline Toprak (3) & HBM4, HBM5 \\
\hline Toprak (4) & HBM6 \\
\hline Toprak (5) & HBM7 \\
\hline Toprak (6) & HBM8 \\
\hline Toprak (7) & HBM9 \\
\hline Su (1) & - \\
\hline Su (2) & - \\
\hline
\end{tabular}

YEP Agar besiortamında gelişen maya kolonileri saflaştırımıştır (Şekil 2). Saflaştırılan kolonilerin vejetatif hücre yapıları 100x immersiyon objektifinde incelenmiştir (Şekil 3).

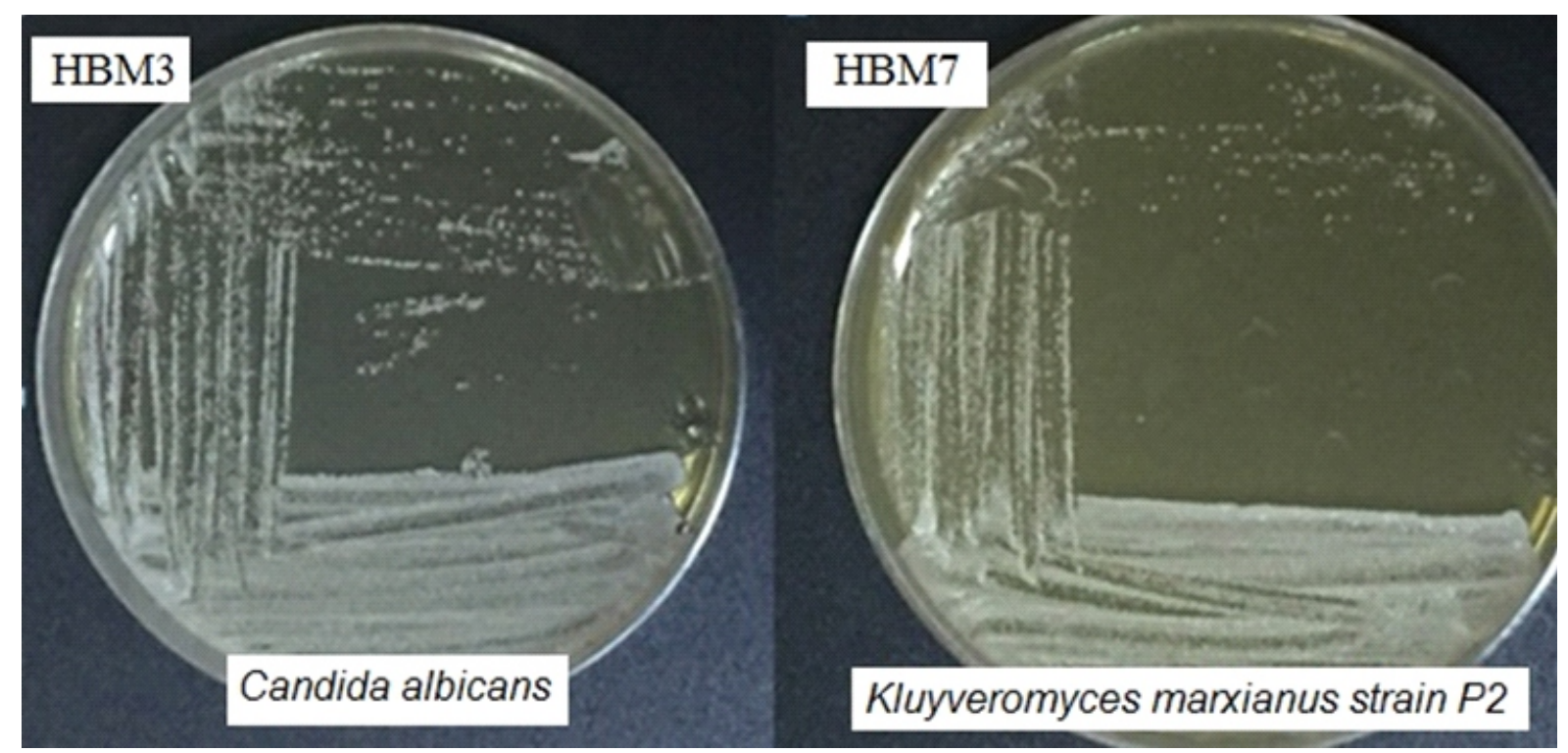

Şekil 2.İzolasyonu yapılan bazı maya kolonilerinin YEP Agar besiortamında görüntüsü

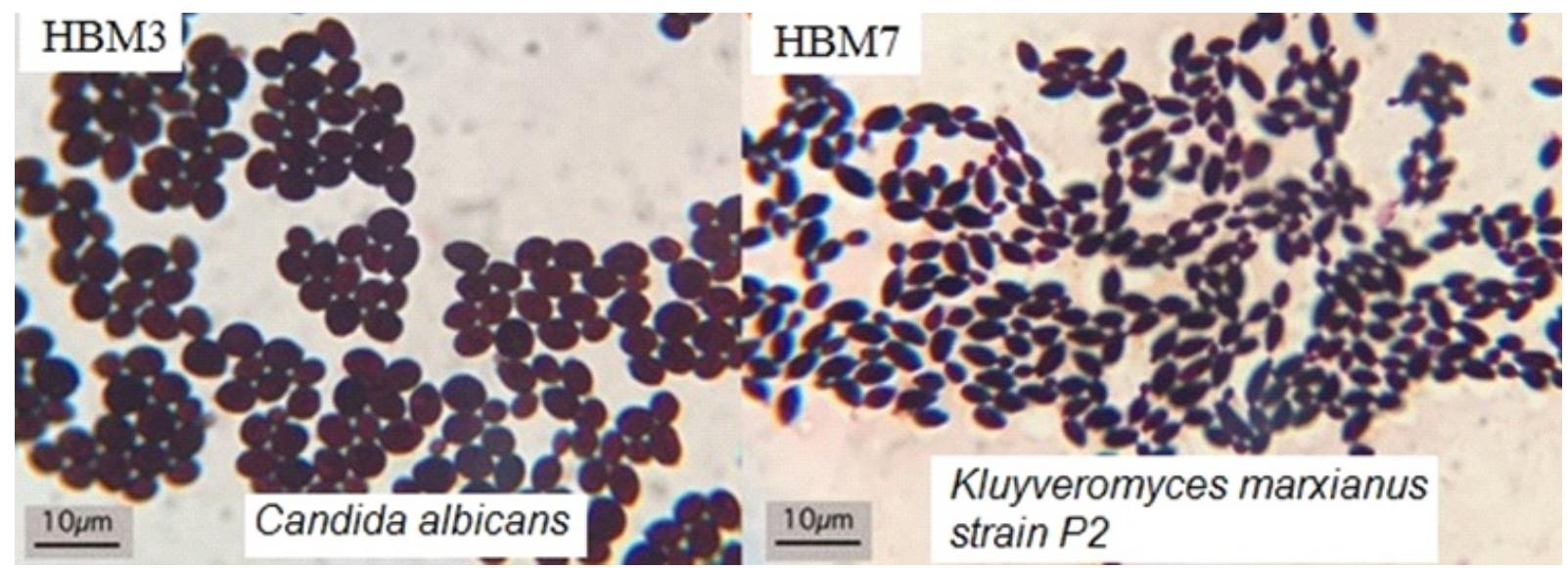

Şekil 3.Saflaştııılan izolatlara ait vejetatif hücre yapılarının 100x immersiyon objektifindeki mikroskobik görüntüsü 


\section{Moleküler Tanılama}

HBM1, HBM2; HBM3, HBM4, HBM5, HBM6, HBM7, HBM8, HBM9 olarak numaralandırılmış 9 izolata ait DNA'ların agaroz jel elektroforezindeki görüntüsü verilmiştir (Şekil 4).

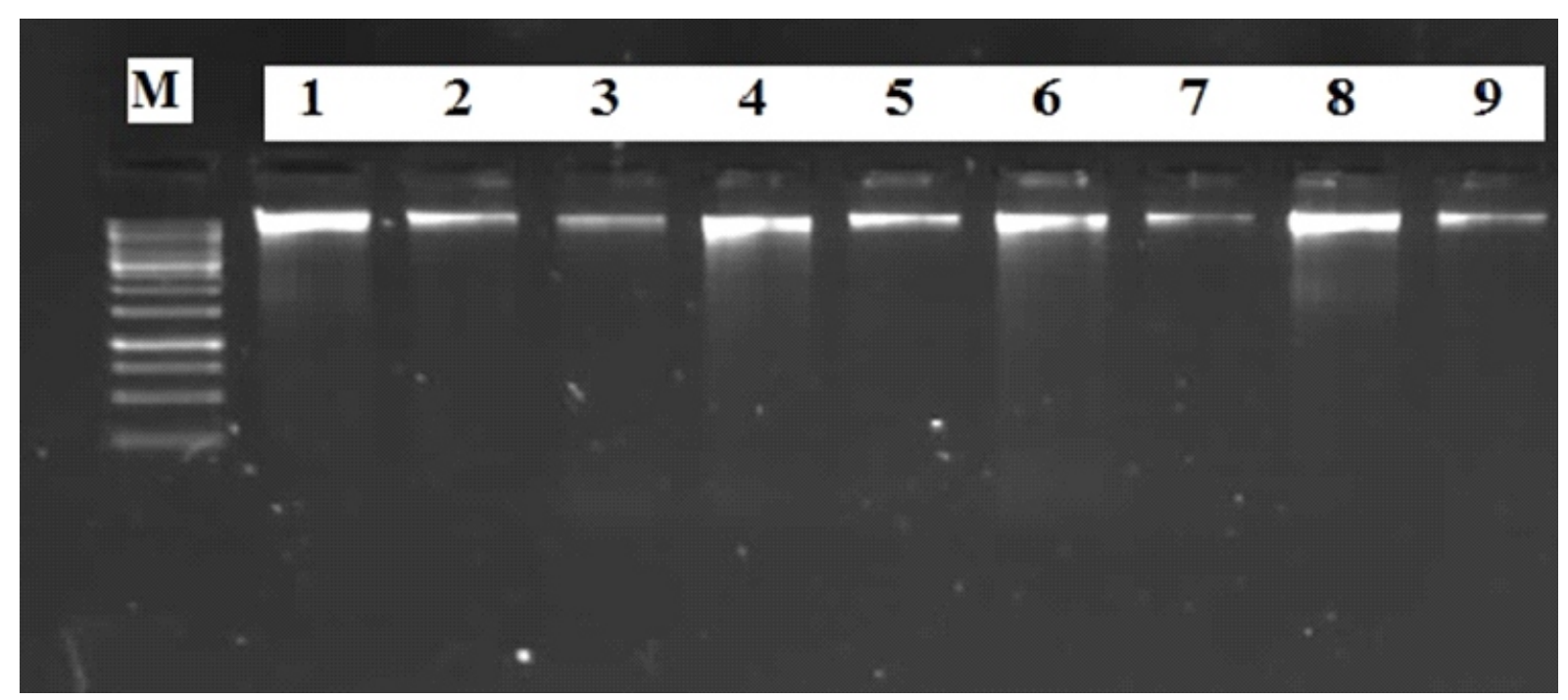

Şekil 4. 9 izolatın toplam DNA'larının agaroz jel elektroforezi görüntülenmesi.

Marker olarak 1kb'lık DNA Ladder kullanılmıştır. 1:HBM1, 2:HBM2; 3:HBM3; 4:HBM4; 5:HBM5; 6:HBM6; 7:HBM7; 8:HBM8; 9:HBM9

Total DNA konsantrasyonu ve DNA kirliliğinin NanoDrop'ta ölçüm değerleri (Tablo 2)' de verilmiştir.

Tablo 2. Total DNA konsantrasyonu ve DNA kirliliğinin NanoDrop'taki ölçümü

\begin{tabular}{c|c|c|c|}
\hline İzolat Numarası & Nükleik Asit $\mathbf{n g} / \boldsymbol{\mu L}$ & $\mathbf{2 6 0 / 2 8 0 ( A b s )}$ & Örnek Tipi \\
\hline HBM1 & $136,5 \mathrm{ng} / \mu \mathrm{L}$ & 1,92 & DNA \\
\hline HBM2 & $806,5 \mathrm{ng} / \mu \mathrm{L}$ & 1,73 & DNA \\
\hline HBM3 & $577,9 \mathrm{ng} / \mu \mathrm{L}$ & 1,86 & DNA \\
\hline HBM4 & $989,6 \mathrm{ng} / \mu \mathrm{L}$ & 2,01 & DNA \\
\hline HBM5 & $711,2 \mathrm{ng} / \mu \mathrm{L}$ & 1,78 & DNA \\
\hline HBM6 & $1038,4 \mathrm{ng} / \mu \mathrm{L}$ & 1,83 & DNA \\
\hline HBM7 & $639,3 \mathrm{ng} / \mu \mathrm{L}$ & 1,97 & DNA \\
\hline HBM8 & $281,2 \mathrm{ng} / \mu \mathrm{L}$ & 1,88 & DNA \\
\hline HBM9 & $412,4 \mathrm{ng} / \mu \mathrm{L}$ & 1,91 & DNA \\
\hline
\end{tabular}

PCR ürünleri Agaroz Jel Elektroforezinde yürütülmüş ve UV ışığında jel görüntüsü alınmıştır (Şekil 5).

Elde edilen sekansların BioEdit 7.1.3 programı kullanılarak, baz dizilimleri ve hizalamaları yapılmıştır. Hizalama yapıldıktan sonra elde edilen diziler NCBI Blast (http://www.ncbi.nlm.nih.gov/blast/Blast.cgi) ile GenBank'taki kayıtlı dizilerle karşılaştııılmış ve türler tespit edilmiştir.
HBM1, HBM3, HBM4, HBM5, HBM6, HBM7, HBM8 ve HBM9 numaralı izolatların GenBank'ta kayıtlı türlerle benzerliği bulunmasına rağmen izolat HBM2'nin GenBank'ta karşılığı tespit edilememiştir. Bu nedenle toplam 8 izolatın GenBank'taki karşılığı saptanmıştır. İzolatların numaraları, tür isimleri, accession numaraları, depolanmış türlere benzerlik yüzdeleri ve identifikasyon skorları Tablo 3'de verilmiştir. 


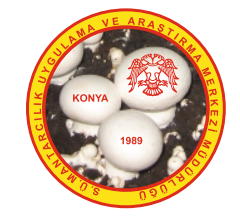

\section{\begin{tabular}{l|llllllllllll}
$M$ & 1 & 2 & 3 & 4 & 5 & 6 & 7 & 8 & 9 & 10 & 11 & 12
\end{tabular}}
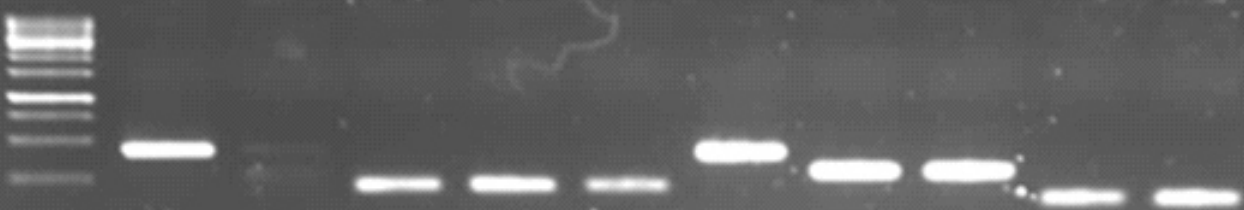

9

Şekil 5. Maya izolatlarına ait PCR ürünlerinin agaroz jel elektroforezinde görüntülenmesi (1. kuyucuk: HBM1; 2. kuyucuk: HBM2; 3. kuyucuk: HBM3; 4. kuyucuk: HBM4; 5. kuyucuk: HBM5; 6. kuyucuk: HBM6; 7. ve 8. kuyucuk: HBM7; 9. ve 10. kuyucuk: HBM8; 11. ve 12.. kuyucuk: HBM9; M:1kb DNA Ladder, 100bç- 2500bç).

Tablo 3. Elde edilen sekansların GenBank'taki kayıtlı dizilerle karşılaştırılmaları ve tespit edilen tür isimleri

\begin{tabular}{|c|c|c|c|c|}
\hline $\begin{array}{c}\text { İzolat } \\
\text { Numarası }\end{array}$ & Tür İsmi & $\begin{array}{c}\text { Accession } \\
\text { Numarası }\end{array}$ & Benzerlik (\%) & Max. Skor \\
\hline HBM1 & $\begin{array}{c}\text { Saccharomyces } \\
\text { cerevisiae strain } \\
\text { levure } 23\end{array}$ & KT726925.1 & 98 & 307 \\
\hline HBM2 & $\begin{array}{l}\text { DNA'sı elde edilmiş } \\
\text { fakat tür ismi tespit } \\
\text { edilememiştir. }\end{array}$ & - & - & - \\
\hline HBM3 & Candida albicans & GU373665.1 & 99 & 318 \\
\hline HBM4 & $\begin{array}{l}\text { Candida albicans } \\
\text { strain H295B }\end{array}$ & KP675008.1 & 99 & 316 \\
\hline HBM5 & $\begin{array}{l}\text { Pichia jadinii strain } \\
\text { ATCC } 22023\end{array}$ & AF335929.1 & 99 & 321 \\
\hline HBM6 & $\begin{array}{c}\text { Saccharomyces } \\
\text { cerevisiae }\end{array}$ & KP998094.1 & 99 & 311 \\
\hline HBM7 & $\begin{array}{c}\text { Kluyveromyces } \\
\text { marxianus strain P2 }\end{array}$ & KF851351.1 & 99 & 398 \\
\hline HBM8 & $\begin{array}{c}\text { Pichia manshurica } \\
\text { strain } \mathrm{H} 79 \mathrm{a}\end{array}$ & KP674783.1 & 98 & 283 \\
\hline HBM9 & $\begin{array}{c}\text { Candida glabrata } \\
\text { strain } 86 \mathrm{~A}\end{array}$ & KP764981.1 & 98 & 297 \\
\hline
\end{tabular}

Tablo 3'deki mayalar, Adnan Menderes Üniversitesi, Fen/Edebiyat Fakültesi, Biyoloji Bölümü, Mikrobiyoloji Laboratuvarı stoklarında kodlanan izolat numaralar ile liyofilize halde saklanmaktadır. 


\section{Filogenetik Analiz Sonuçları}

Filogenetik ağacın oluşturulması için MEGA 6 programı kullanıımıştır. GenBank'dan elde edilen referans organizmaların ve bu çalışmada elde edilen izolatların baz dizileri programa yüklenmiştir. MEGA6 bünyesinde yer alan ClustalW programı kullanılarak, baz dizi benzerliklerine göre sıralanmıştır. MEGA 6 programının 1000 tekrarlı "Bootstrap test of phylogeny" özelliği seçilerek "neighbourjoining" özelliğine dayalı olarak filogenetik ağaç oluşturulmuştur. Bu yöntemde taksonlar arasındaki yakınlık analiz edilmiştir.

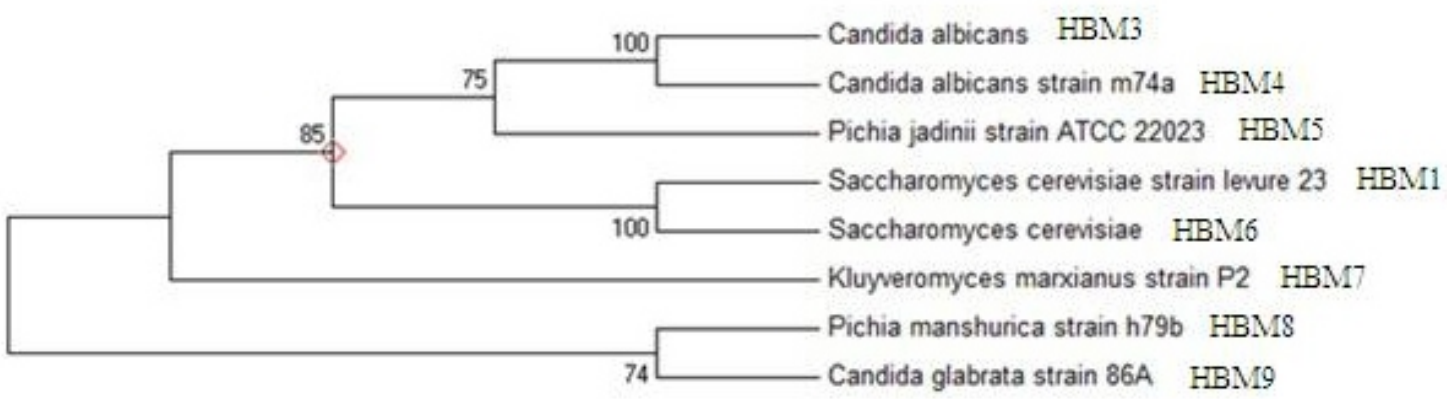

Şekil 6. Suşların MEGA6 programı kullanılarak oluşturulan filogenetik ağacı. Dalların yanındaki rakamlar istatiksel bootstrap değerlerini göstermektedir. İstatistiksel olarak ağaçtaki verilere göre türler arasındaki \% benzerlik ve yakınlık dereceleri hakkında bilgi elde edilmiştir

\section{Tartışma}

Termofilik mayalar bacteria ve archaea türleri gibi daha yüksek sıcaklıklarda yaşamaya adapte olamazlar ve $60^{\circ} \mathrm{C}$ 'nin üzerinde yaşayan ökaryotikler de yoktur. Üstelik $60^{\circ} \mathrm{C}$ 'nin üzerinde ökaryötik organeller yaşayamaz ve sadece prokaryötik yaşam formları olabilir (Madigan ve ark., 2015). Bu yüzden $40^{\circ} \mathrm{C}$ 'nin üzerindeki sıcaklıklarda yaşayanlar termotolerant/termofilik mayaların temsilcileri olabilir (Arthur ve Watson, 1976). Psikrofilik ve termofilik terimleri tanımlanırken organizmanın maya mı, ekstrem çevredeki prokaryot mu veya ökaryot mu olduğuna bakılmaksızın sadece türler dikkate alınarak mikroorganizmalara göre yapılmaktadır. Mayaların üst termofilik limiti, termofilik organizmalar için en düşük limit tanımlaması yaklaşık $46^{\circ} \mathrm{C}$ 'dir (Arthur ve Watson 1976; Madigan ve ark., 2015).

Ökaryotlardan birçoğu, $40-45^{\circ} \mathrm{C}^{\prime}$ den yüksek ısılarda yaşamadıkları için termofilik mantarlar da uzun süre fark edilmemiştir. Bir asır önce Lindt tarafından ekmekten ilk termofilik mantar Mucor pusillus izole edilmiş, ardından Tsiklinskaia tarafından Thermomyces lanuginosus patatesden izole edilmiştir. $\mathrm{Bu}$ küflerin her ikisi de tesadüfen keşfedilmişlerdir. Hugo Miehe, termofilik mantarlar ile ilgili geniş araştırmalar yapan ilk kişi olmuştur. Miehe'in yaptığı çalışmalardan dolayı termofilik mantarların temel yaşam koşulları belirlenmiştir. Cooney ve Emerson izole ettikleri 13 termofilik mantar türünü yaşama ortamlarına göre sınıflandırmış ve bu alanda çalışmaların artmasını sağlamışlardır (Deacon, 2007).

Termofilik mayaların hepsinde olmasa da, bazılarında sitoplazmik zara bağlı yağ dolu cisimcikler görülmüştür. Ayrıca bu yapıların endoplazmik retikulumda da devam ettiği gösterilmiştir. Asıl lipit depolanması, $50{ }^{\circ} \mathrm{C}$ 'de değil, $37^{\circ} \mathrm{C}$ 'de üreyen hiflerde bulunur. Bu yağ cisimcikleri henüz tam anlaşılmamakla birlikte, termofili mekanizması ile ilişkili olduğu düşünülmektedir (Hudson, 1987).

Termofilik mantarlar bulundukları yerlere göre, jeotermal bölgelerde üreyenler ve çürümüş bitki kümeleri, gübre gibi kendini ısıtan (selfheating) kaynaklarda üreyenler olmak üzere iki gruba ayrılmışlardır. 
Jeotermal topraklar, dünyada birçok yerde bulunur. Amerika Birleşik Devletleri'nde Yellowstone Milli Parkı'nda bu tür sıcak su kaynakları bulunmaktadır. Buradaki toprağın özelliği, ısısının $70^{\circ} \mathrm{C}$ ve daha fazla olması, ağır metaller içermesi, pH'sının 2-7 arasında veya daha az olması, az organik madde içermesidir (Redman ve ark., 1999).

Dünyamız'da solfatarik alanlar, hidrotermal kuyular, sıcak su kaynakları gibi çeşitli jeotermal alanlardan aerobik termofillerin izolasyonları yapılmaktadır (Baker, 2001). Yapılan çalışmalarda, sıcaklığın mikroorganizmaların fizyolojik aktiviteleri ve gelişimleri üzerindeki en önemli faktörlerden biri olduğunu göstermiştir. Jeotermal kaynaklar açısından oldukça zengin olan ülkemizde resmi kayıtlara alınmış 140 adet jeotermal saha bulunmaktadır. İller bankasının 2001 yılında yayınlamış olduğu listeye göre ülkemizdeki jeotermal kaynaklar ve kuyu başı sıcaklıkları da verilmiştir, bu kaynaklardan bazıları da Aydın ilinde bulunmaktadır (Anonim, 2001).

Aslında bu tür mantarlar çevremizde çok yaygındır. Isısı 40-50 ${ }^{\circ} \mathrm{C}$ olan sıcak sulardan, topraktan, sıcak havuzlardan, yağmur ormanlarının etrafından, çamurdan, ağaç yapraklarından, topraktan hem mezofilik hem de termofilik mantarlar bir arada izole edilmiştir (Deacon, 2007).

Aydın ili Buharkent Bereket Jeotermal Su kaynağı çevresine bırakılan termal suların sıcaklığının minimum $65^{\circ} \mathrm{C}$ olduğunu bilindiğine göre bulgulardan elde edilen veriler termofilik mayaların bu tür çevrelerde yaygın olgunun bir göstergesidir.

Günümüzde mayaların tanılanmalarında kullanılan kültürel yöntemlerin geçerliliği olmasına rağmen mayaların morfolojik, fizyolojik ve üreme gibi fenotipik özelliklerinde meydana gelebilecek değişiklikler her zaman genotipik özellik olarak yansımamaktadır (VaughanMartini, 2003). Bu nedenle klasik yöntemlerle yapılan tanılamada hata payının fazla olması, tekrarlanabilirlik yüzdesinin düşük olması ve zaman kaybına sebebiyet vermesi mümkün olduğu için son yıllarda araştırmacılar tanıla- mada moleküler metotları kullanmaya yönelmişlerdir. DNA esaslı olarak PCR teknolojisinin geliştirilmesiyle mayaların hızlı, doğru ve güvenilir bir şekilde tür ve suş düzeyinde tanımlanmaları mümkün olabilmektedir. Özellikle ribozomal RNA (rRNA) veya ribozomal DNA (rDNA)'daki belirli bölgelerin hedeflendiği çeşitli teknikler günümüzde sıklıkla kullanılmaktadır. PCR ile çoğaltılmış DNA bölgesinin restriksiyon enzimleri ile kesimine dayanan RFLP (Restriction Fragment Length Polymorphism) ve RAPD (Randomly Amplified Polymorphic DNA) kullanılan yöntemler arasındadır. Tanılamada kullanılan DNA esaslı bu yöntemler; 26S rDNA, 18S rDNA veya 18rDNA' daki ara bölgelerin (ITS1 ve ITS2) tanımlanmasına yöneliktir (Hierro ve ark., 2004).

Mayaların tür tespiti ve türler arası ilişkilerinin belirlenmesinde ITS bölgelerinin kullanılması yaygındır. ITS bölgeleri ribozomal RNA içerisinde tekrarlanan bir bölgedir. Bu bölgede $5^{\prime}$ external transcribed sequence (5' ETS), 18S rRNA, ITS1, 5.8S rRNA, ITS2, 28S rRNA ve son olarak da 3' ETS bölgeleri bulunmaktadır. Mayaların tanılanmasında ITS bölgesinin; ITS1, ITS2, ITS5, ITS3 ve ITS4 primerleri ile çoğaltıldıkları bilinmektedir (Schoch ve ark., 2012).

Arxiozyma telluris (= Kazachstania telluris) mayası 28 ve $45^{\circ} \mathrm{C}$ arasında dar bir büyüme sıcaklığı gösterdiği için zorunlu termofilik olarak sınıflandırıımıştır. A. telluris'ün etanol de $37^{\circ} \mathrm{C}$ 'de büyütüldüğü zaman maksimum hücre verimine ulaştığı görülmüştür. $25^{\circ} \mathrm{C}$ 'de büyüme oldukça yavaş ve $20^{\circ} \mathrm{C}$ 'de ise hiçbir büyüme gözlenmemiştir, üstelik bu termotolerant Candida parapsilosis mayasından ziyade daha çok termofilik bir karaktere sahip tür olduğunu gösterir. $A$. telluris'in büyüme için üst büyüme sıcaklığı yaklaşık $45^{\circ} \mathrm{C}$ idi (Arthur ve Watson 1976).

Kore'de topraktan izole edilen Y94T maya suşu daha yüksek sıcaklıklarda büyüme kapasitesine sahiptir. Suş, çoklu tomurcuklanma ile eşeysiz üreme, nişasta gibi ekstraselüler bileşiklerin yokluğu, negatif bir diazonyum 
mavisi B renk reaksiyonu ve artrosporlar, balistik konidya ve askosporların yokluğu gibi karakteristik özelliklere sahip olduğundan Candida genusu içine yerleştirilebilir. Diğer belirli fizyolojik karakterleri yanında maksimum büyüme sıcaklığı $50-51^{\circ} \mathrm{C}$ olan ve diğer askomiset mayalardan ayrışan kısmi tek $26 \mathrm{~S}$ ribozomal DNA Iı bu suşdur. Bu yeni suş Candida thermophila olarak tanılanmıştır (Shin ve ark.,2001).

Çalışmada ITS bölgeleri kullanılarak yapılan moleküler tanılama sonucu \% 98 oranın da benzerlikle maya izolatlarının tanıları yapılmıştır. Sadece bir türün tanısı yapılamamıştır. Bu da bize uygulanan tekniklerin termofilik çevredeki mayaların izolasyon ve tanısı için geçerli bir yöntem olduğunu göstermektedir.

Bulgularımız olan Candida albicans, Candida albicans strain m74a, Pichia jadinii strain ATCC 22023, Saccharomyces cerevisiae, Kluyveromyces marxianus strain P2, Pichia manshurica strain h79b ve Candida glabrata strain 86A türleri, ülkemiz ve Aydın bölgesindeki jeotermal kaynakların bulunduğu yerlerdeki topraktan alınan ilk termofilik maya örnekleri olabilir. Çünkü kayıtlarda bu termofilik maya örneklerine rastlanmamıştır.

Dünya literatür kaynaklarında mayaların çeşitli çevrelerden izolasyonu ve tanılarının ITS bölgeleri kullanılarak yapıldığını gösteren fazlaca çalışmalar vardır. Senses-Ergul ve ark., (2006) gıdalardan izole edilen bazı mayaların hem klasik hem de moleküler metotlarla identifikasyonunu gerçekleştirmişlerdir. İzole edilen 22 adet maya suşunda ITS-18S rRNAgen bölgesi sekanslanmış ve Candida parapsilosis, Rhodotorula mucilaginosa, Debaryomyces hansenii, Cryptococcus humicolus, Cryptococcus albidus, Aureobasidium spp., Hanseniaspora valbyensis, Metschnikowia pulcherrima, Lachancea thermotolerans, Pichia anomala, Geotrichum candidum, Yarrowia lipolytica olarak tanılanmıştır. Fitzpatric ve ark., (2006) izole ettikleri fungusların filogenetik identifikasyonu sonucunda Candida Iusitaniae, Candida guilliermondii, Debaryomyces hansenii, Candida albicans, Candida dubliniensis, Candida tropicalis, Candida parapsilosis ve Lodderomyces elongisporus mayalarını tanılamışlardır. Tofalo ve ark., (2009) şaraptan izole ettikleri mayaların ITS gen bölgelerini sekanslayarak, Candida apicola, Candida zemplinina ve Zygosaccharomyces bailii olarak osmotolerant maya türlerini identifiye etmişlerdir. Choi ve ark., (2010) topraktan 2 maya suşu izole etmişler ve ITS1 ve ITS2 gen bölgelerini sekanslayarak, Saccharomyces cerevisiae olarak belirlemişlerdir. Gonz'alez-Hern'andez ve ark., (2012) etanol üretiminde kullanılan mayaların izolasyonunu ve moleküler identifikasyonunu gerçekleştirmişlerdir. RFLP yöntemini kullanarak Saccharomyces cerevisiae maya türünü tanımlamışlardır. Kurtzman ve Robnett (2013) izole ettikleri maya suşlarının filogenetik identifikasyonunu yapmışlar ve Pichia sp., Saturnispora sp., Kregervanrija sp., Dekkera sp., Ogataea sp, Ambrosiozyma sp., Barnettozyma sp., Cyberlindnera sp., Phaffomyces sp., Starmera sp., Wickerhamomyces sp., Kodamaea sp., Metschnikowia sp., Debaryomyces sp., Zygoascus sp., Yarrowia sp. olarak belirlemişlerdir. El-Latif Hesham ve ark., (2014) peyniraltı suyu gibi endüstriyel atıklardan izole ettikleri maya suşunun 5.8S-ITS rDNA ve 26S rRNA gen bölgelerinin sekansını yapmışlar ve \%99 benzerlikle Kluyveromyces marxianus ve Kluyveromyces lactis olarak belirlemişlerdir. Šuranská ve ark., (2016) beyaz peynirden izole ettikleri maya suşlarının identifikasyonu için ITS gen bölgelerini kullanmışlar ve Debaryomyces hansenii, Kluyveromyces lactis, Candida zeylanoides, Yarrowia lipolytica, Galactomyces geotrichum maya suşları tanılanmıştır. AbdelSater ve ark., (2016) deri ve tırnak örneklerinden izole edilen 21 maya suşunun ITS gen bölgelerini sekanslayarak Saccharomycopsis fibuligera, Candida galli ve Trichosporon dohaense olarak tanılanmıştır. 
Benzer yöntemler ile termofilik maya türlerini tanılamamız Candida Pichia ,Saccharomyces ve Kluyveromyces cinslerine ait türler tanılamamız kullanılan tanı yönteminin geçerliliği açısından oldukça önemlidir.

Suşların MEGA6 programı kullanılarak oluşturulan filogenetik ağacında; Moleküler tanılama için kullanılan DNA bölgesinde oluşabilecek bir nokta veya bölgesel bir mutasyon, dizileme sırasında oluşan bir gap veya yanlış eşleşmeler baz dizi verisinde değişmeye yol açabileceği için filogenetik ağaç oluşturan programın farklı yorumlamasına yol açmış olabilir. Bu değişiklikler tür tayinini etkilemese de filogenetik ağaç çıkarırken farklılıklara yol açabilmektedir

Ege bölgesi ve özellikle Aydın ili jeotermal kaynakların en fazla olduğu illerimizden biridir. Aydın ilinde jeotermal kaynaklardan izole edilen termofilik mikroorganizmalar; özellikle bakteriler ve mikrofunguslar ile ilgili çalışmalar oldukça fazladır. Termofilik mayalar ve bunların taksonomisi ile yapılan çalışmalar oldukça azdır. Termofilik mikroorganizmaların biyoteknoloji ve enzim biyoteknolojisinde kullanımının önemi göz önünde bulundurulduğunda toprak ve su örneklerinden izole edilen 8 termofilik mayanın izolasyon ve tanısının katkısı yadsınamaz. Çalışmamızda termofilik çevreden alınan toprak ve su örneklerinden izole edilen 9 maya suşunun ITS1 ve ITS2 gen bölgeleri çoğaltılarak, sekans analizi yapılmıştır. Termofilik mayalar kayıt altına alınarak stoklarımıza girmiştir. Böylece elde edilen suşların endüstriyel potansiyellerin araştırılması ve bir sonraki çalışmalar için kullanım olanağı sağlayacağı düşünülmektedir.

\section{Teşekkür}

Bu çalışma TÜBITAK-BIDEP 2209 (Proje No: 1919B011500712) projesi ile desteklenmiştir.

\section{Kaynaklar}

Abdel-Sater M.A., Moubasher A.A., Soliman Z. Identification of three yeast species using the conventional and internal transcribed spacer region sequencing methods as first or second global record from human superficial infections, Mycoses, 59(10)652-661 (2016).

Anonim. Kaplıcaya Sahip Belediyeler Birliği (2001).

Arthur H., Watson K. Thermal adaptation in yeast: growth temperatures, membrane lipid, and cytochrome composition of psychrophilic, mesophilic, and thermophilic yeasts, Journal of Bacteriology, 128 56-68 (1976).

Baker G.C., Gaffer S., Cowan A.D., Suharto A.R. Bacterial community analysis of Indonesian hot springs, FEMS Microbiology Letters, 200 103-109 (2001).

Charles P.E, Dalle F., Aube H., Doise J.M, Quenot J.P, Aho L.S, Chavanet P., Blettery B. Candida spp. colonization significance in critically ill medical patients: a prospective study, Intensive Care Medicine, 31(3) 393-400 (2005).

Choi G.W., Umb H.J., Kim Y., Kang H.w., Kim M., Chung B.W., Kim Y.H. Isolation and characterization of two soil derived yeasts for bioethanol production on Cassava starch, Biomass and Bioenergy, 34(8) 1223-1231 (2010).

Deacon J. The microbial world: Thermophilic microorganisms produced by institute of Cell and Molecular Biology. The University of Edinburgh, (http://helios.bto.ed.ac.uk/bto/microbes/thermo.htm.)(2007).

Dlauchy D., Tornai-Lehoczki J., Peter G. Restriction enzyme analysis of PCR amplified rDNA as a taxonomic tool in yeast identification, Systematic and Applied Microbiology, 22(3) 445-53 (1999).

El-Latif Hesham A., Wambui V., Henry Ogola J.O., Maina J.M. Phylogenetic analysis of isolated biofuel yeasts based on 5.8S-ITS rDNAand D1/D2 26S rDNA sequences, Journal of Genetic Engineering and Biotechnology, 12(1) 37-43 (2014). 


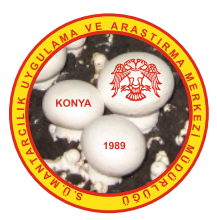

Fernandez-Espinar M.T, Martorell R., De Llanos R., Querol A. Molecular methods to identify and characterize yeasts in food sand beverages. In: Yeasts in food and beveragesed: Querol A. and Fleet G (eds), Springer-Verlag, Berlin, Germany, p. 55-82, (2006).

Fitzpatric D.A., Logue M.E., Stajich J.E., Butler G. A fungal phylogeny based on 42 complete genomes derived from supertree and combined gene analysis, BMC Evolutionary Biology, 6(99) 1-15 (2006).

Genç T.T., Çıldır İ.N. Bozcaada üzüm çeşitleri üzerinde Non-Saccharomyces mayaların dağııımı, Biyoloji Bilimleri Araştırma Dergisi, 5(1) 115-120 (2012).

Gonz'alez-Hern'andez J.C., Perez E., Damian R.M., Chavez-Parga M.C. Isolation, molecular and fermentative characterization of a yeast used in ethanol production during mezcal elaboration, Revista Mexicana de Ingeniería Química, 11(3) 389-400 (2012).

Hierro A., Sun J., RusnakA.S., Kim J., Prag G., Emr S.D., Hurley J.H. Structure of the ESCRT-II endosomal trafficking complex, Nature, 431(7005) 221-225 (2004).

Hoffman C.S., Winston F. A ten-minute DNA preparation from yeast efficiently releases autonomous plasmids for trans formation of Escherichia coli, Gene, 57(2) 267-272(1987).

Hundson H.J. Fungal Biology. Edward Amold Press, London, 6 158-75 (1987).

Kurtzman C.P., Robnett C.J. Relationships among genera of the Saccharomycotina (Ascomycota) from multigene phylogenetic analysis of type species, FEMS Yeast Research, 13(1) 23-33 (2013).

Madigan MT, Martinko JM, Parker J. Brock biology of microorganisms, 14th edn. Pearson Education Limited (2015).

Lee B.H. Fundamentals of food biotechnolology, VCH Publishers, USA, p. 431, (1996).

Lopes M.B, Soden A., Martens A., Henschke P.A, Langridge P. Differentiation and species identification of yeasts using PCR, International Journal of Systematic Bacteriology, 48(1) 279-286 (1998).

Pfaller M.A., Diekema D.J. Rare and emerging opportunistic fungal pathogens: Concern for resistance beyond Candida albicans and Aspergillus fumigatus, Journal of Clinical Microbiology, 42(10) 44194431 (2004).

Redman R.S, Litvintseva A., Sheehan K.B., Henson J.M., Rodringuez R.J. Fungi from geothermal soils in Yellowstone National Park. Applied and Environmental Microbiology, $655193-7$ (1999).

Schoch C.L., Seifert K.A., Huhndorf S., Robert V., Spouge J.L., Levesque C.A., Chen W., Consortium F.B. Nuclear ribosomal internal transcribed spacer (ITS) region as a universal DNA barcode marker forfungi, Pnas, 109(16)6241-6246 (2012).

Senses-Ergul Ş., Agoston R., Belak A., Deak T. Characterization of some yeasts isolated from foods by traditional and molecular tests, International Journal of Food Microbiology, 108(1) 120-124 (2006).

Shin K.S, Shin Y.K, Yoon J.H, Park Y.H. Candida thermophila sp. nov., a novel thermophilic yeast isolated from soil, International Journal of Systematic Evolutionary Microbiology, 51 2167-2170, (2001).

Šuranská H., Raspor P., Uroić K., Golić N., Kos B., Mihajlović S., Begović J., Šušković J., Topisirović L., Čadež N. Characterisation of the yeast and mould biota in traditional white pickled cheeses by culture-dependent and independent moleculartechniques, Folia Microbiologica (Praha), 61(6) 455463 (2016).

Tofalo R., Chaves-López C., DiFabio F., Schirone M., Felis G.E., Torriani S., Paparella A., Suzzi G. Molecular identification and osmotolerant profile of wine yeasts that ferment a high sugar grape must, International Journal of Food Microbiology, 130(3) 179-187 (2009).

Van den Burg B. Extremophiles as a source for novel enzymes, Current Opinion Microbiology, 6(3), 213218 (2003).

Van Der Vossen J.M.B.M., Rahaoui H., De Nijs M.W.C.M.,Hartog B.J. PCR methods for tracing and detection of yeasts in the food chain. In: Yeasts in Food, Boekhout T, Robert V (eds), BayerleinGmbH, Neusass, Germany, p. 123-137, (2003). 
Vaughan-Martini A. Reflections on the clasification of yeasts for different end-users in biotechnology, ecology, and medicine, International Microbiology, 6(3) 175-182 (2003).

White T.J., Bruns T., Lee S., Taylor J.W. Amplification and direct sequencing of fungal ribosomal RNA genes for phylogenetics. In: Innis, M.A.,Gelfand, D.H., Snissky, J.J., White, T.J. (Eds.), PCR protocols: Aguide to method sand applications. AcademicPressInc.,NewYork, p. 315-322, (1990).

Zhang Y., Wu W.P., Hu D.M., Su Y.Y., Cai L. A new thermophilic species of Myceliophthora from China, Mycological Progress, 13(1)165-170 (2014). 